Leadership

\section{and Innovation in Schools}

\section{Jack Dixon and Raymond Chodzinski}

I first met Jack Dixon more than thirty-five years ago. He was a teacher in the Hasting County School Board. Over the years I have come to know him as an energetic, dynamic, creative individual who is forever extremely pleasant and collegial. During his career he sponsored many innovate leadership initiatives and has influenced the shape of education in Hasting County and the Province. His career in education is varied. He has served as a teacher, consultant, counsellor, vice-principal and principal in schools and taught at Brock University and now Loyalist College. Much of his career has been devoted to the development and application of innovation in schools particularly new programs that further the boundaries of how education services are delivered within the institutional setting. If I were to provide Jack with a motto it would be that there are no boundaries only challenges. We met for a day and I interviewed Jack about his thoughts on leadership in schools. What he had to say could very easily become a book on leadership in education and in the community at large. What follows is my summary of aspects of that interview.

Chodzinski: What does the phrase leadership in schools mean to you?

Dixon: First it does not mean that the term is personified by being a principal or vice-principal or any administrator for that matter. Of course power and opportunity are more apt to be in the control of an administrator. That said, from my perspective, it is most often the classroom teacher who is at the root of most innovative change and therefore leadership in schools. Administrators can make or break a school and they can definitely influence policy and procedures but without the support and willingness of teachers to introduce and implement innovation all the administrative leadership in the world will not bring about change.

Chodzinski: From your perspective is all leadership about change?

Dixon: Well I think so in that when we speak of leadership in schools we are usually talking about changing something, making things better, rethinking existing practices and moving forward. The classroom teacher is instrumental in this regard. Teachers need to know how to apply pressure to effect change and to mobilize parent and student support through collaborative efforts. This will also include assessing the politics of the day and becoming astute about what is needed and why. So too, Faculty of Education professors need to work with schools to bring about innovation as a result of research. There seems to be very little influence by Faculties of Education other than the standard procedure of introducing new candidates to schools and supervising teaching practice.

Chodzinski: You have been involved in many leadership activities. Please share some with our readers.

Dixon: I have been fortunate to work with innovative individuals such as Eric Runnacres, Bruce Mathers, yourself included and others who have mentored my ongoing need to reach out to the community and influence how education is delivered to students, particularly those in need. Aside from becoming a principal early in my career in Hastings County and CFB Trenton for many years I helped develop an innovative coop program ten years before the term was introduced into Ontario Education. I was instrumental, along with others in founding the Quinte Alternative School Program, an alternative high school that focused on academic, social, physical and emotional dimensions of the education relationship. I taught on the very first Ontario Attendance Counsellors course with Orval Watson and Bob Cairns, the pioneer version of the one you developed and implemented as a degree program at Brock, and helped implement the elementary school guidance counselor program in the Province. I have served on many Ministry of Education and school board committees. More recently, I assisted administration at Loyalist College of Belleville to develop and implement its first Bachelors Degree program in Human Services Management. One of my proudest accomplishments is that I was influential in turning around the $\mathrm{O}^{\prime} \mathrm{Hara}$ Mills Pioneer Village project for Quinte Conservation in Hastings County and it now is a successful part of the historical landscape of Centre Hastings. My point for sharing these projects is that there is always an opportunity to provide leadership. What one needs to do is seize the moment and take action.

Chodzinski: What strategies can you provide for those interested in assuming leadership opportunities in schools and communities?

Dixon: I say first don't be afraid to voice your creative ideas. Stay focused and influence others to support your idea. Develop a sense of need and find ways to address that need in ways that have not been tried before. The most important thing is that one must learn to put ideas into practice. For that one needs to formulate a plan, present 


\section{TEACHING \& LEARNING}

the idea to others who you believe might be interested and that you sense can help, get people on board, encourage others to participate and most of all take a risk.

Teachers should listen to staff concerns, take courses, become members of professional associations, and find out what is wanted in the way of leadership. Honestly, for anyone truly interested in becoming a leader there will never be a time when there is nothing to do. To say I am just a teacher is a cop out. Reach out and look around. Take a risk, You may be criticized for stirring up the pot a bit but so what? Change is risk and risk means that some individuals will be threatened. The best advice for teachers is to get to know the system, understand the rules, become involved with the players and enlist support from those that are influential and have the power and authority to act.

Chodzinski: Criticism has been leveled at leadership initiatives in schools because they are often short lived. This is usually because the individual who started the innovation or spearheaded a change strategy moves to another school or school board.

Dixon: Yes, that is a problem and I have encountered this situation many times. Sometimes seed money dries up, networking does not sustain itself and senior management become interested in other goals and objectives, particularly their own. I think also that innovators need to know how to involve others and particularly how to pass on the torch. Sustainability is often dependent on who is willing to pick up the reigns once the original leader has changed environments. It is important also to understand that innovation/change/ leadership in schools must be fluid and emergent.

Chodzinski: I know that you developed a formula for change. Could you please describe it?

Dixon: I call it the wheel of change. I do not claim that this is exactly original thinking because it developed over time and with the help of many others along the way including you. By starting with what I call the "fuzzy steps" one can apply specific planning and engagement strategies to accomplish the goal'. This is by no means an exhaustive overview it is a simple way of organizing a proposed project that works for me.

\section{Wheel of Change \\ 1. FUZZY SITUATION}

Recognizing the need for change

\section{FACTS}

Determine the players. Do the research

\section{PROBLEM DEFINITIONS}

Become clear and concise. Create a structure

\section{GENERATES IDEAS}

Discuss, Brainstorm

\section{EVALUATE}

Individually and group

6. SOLUTION

Create and Produce

\section{ACCEPTANCE}

Communicate Plan-Sell Idea-obtain funding

\section{ACTION}

Implement

\section{REVIEW}

Constantly review and restructure

\section{RENEW and REVISE}

Chodzinski: So what you are saying, Jack, is that if one thinks in "visuals" imagine a pizza cut into ten pieces. Each piece represents an important part of the overall plan. Each piece is distinct and unique, contains many parts, and is important in its own right but is also essential to the whole as is each other piece. You and I have taught together for many years and as you know the premise that I begin very class with is that "a planned teacher is a better teacher". It would seem that

\section{3:2 Spring/Summer 2006}

your wheel applies equally well to teaching as it does to leading and influencing change.

If you could reduce all that we have shared today into one paragraph what would you like our readers to know.

Dixon: I believe the key elements of influencing through leadership are that individuals at the grass roots must be supportive and cooperative. Initiators need to stay focused, understand the process, become aware of the idiosyncrasies of the system in which they work, be optimistic but understand that because it is a system there are constraints and to look for opportunities to provide leadership and implement change. Perhaps the most crucial skill of all is to become networked. The ability to attract others to your project and be supportive is crucial not only for the success of the project but for the well being of the individuals involved. Nothing happens without initiative and the courage to take a risk.
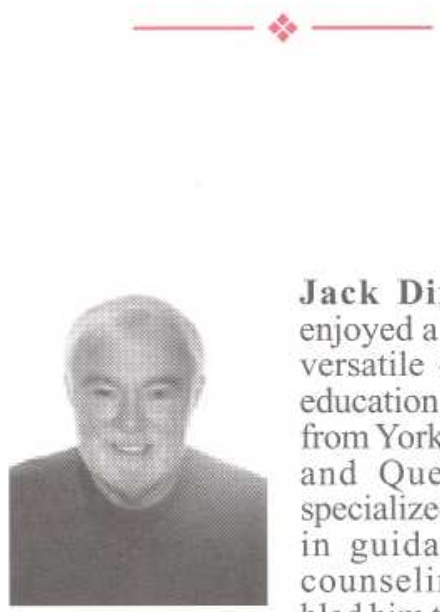

Jack Dixon has enjoyed a long and versatile career in education. Degrees from York, Toronto and Queen, and specialized training in guidance and counseling, enabled him to assume responsibilities in teaching, consulting and administration at the elementary, secondary, Ministry of Education, community college and university levels.

Officially retired, Jack lives about equal time in Belleville, Ontario and Alma, a small fishing village in New Brunswick. He continues to provide leadership in education through workshops and as a professor at Loyalist College in the Bachelor Degree in Human Services Management Program. 